\title{
A teacher-led vicarious contact intervention in culturally mixed classrooms with in- and outgroup role models of intergroup friendship
}

\section{Mäkinen, Viivi}

2019-08

Mäkinen , V , Liebkind , K , Jasinskaja-Lahti , I \& Renvik (Mähönen), T A 2019 , ' A teacher-led vicarious contact intervention in culturally mixed classrooms with in- and outgroup role models of intergroup friendship ', Journal of School Psychology, vol. 75 , pp. 27-40 . https://doi.org/10.1016/j.jsp.2019.07.002

http://hdl.handle.net/10138/333394

https://doi.org/10.1016/j.jsp.2019.07.002

cc_by_nc_nd

acceptedVersion

Downloaded from Helda, University of Helsinki institutional repository.

This is an electronic reprint of the original article.

This reprint may differ from the original in pagination and typographic detail.

Please cite the original version. 


\section{Running head: VICARIOUS CONTACT INTERVENTION}

A teacher-led vicarious contact intervention in culturally mixed classrooms with in- and outgroup role models of intergroup friendship

\footnotetext{
Viivi Mäkinen ${ }^{1}$, Karmela Liebkind ${ }^{1}$, Inga Jasinskaja-Lahti ${ }^{1}$ \& Tuuli Anna Renvik ${ }^{2}$

${ }^{1}$ Department of Social Research (Social Psychology), University of Helsinki, Finland

${ }^{2}$ Open University, University of Helsinki, Finland
}

Corresponding author: Viivi Mäkinen, Department of Social Research (Social Psychology), University of Helsinki, Unioninkatu 37 (P.O. Box 54), 00014 Helsinki, Finland.

E-mail: viivi.m.makinen@helsinki.fi 


\begin{abstract}
Existing prejudice-reduction interventions in schools mainly target majority students and are mostly conducted by researchers, which limits their use for anti-discriminatory practices in culturally mixed schools. We tested a teacher-led intervention aiming at prejudice-reduction among both minority and majority adolescents through vicarious contact. The effects of indirect vicarious contact rest on observed ingroup role models of intergroup contact who have positive attitudes towards the outgroup, and vice versa. However, the specific impact of vicarious contact exerted by outgroup role models in comparison with ingroup role models has never been studied in interventions conducted in naturalistic school settings. To fill these gaps, a field experiment was conducted among secondary school students in Finland $\left(N_{\text {majority }}=437 ; N_{\text {minority }}=146\right)$. The experiment consisted of two stages, between which the ethnic status of the role models (majority vs minority) in stories read during the intervention sessions was changed. This was done to explore the impact of the in- and outgroup role models after the first stage, and to test the overall effect of the intervention on out-group attitudes and perceived in- and outgroup norms after participants were presented with both majority and minority storytellers after the second stage. The intervention affected the perceived outgroup norms among the minority participants as they perceived norms prevailing in the majority group to be more positive after the intervention. However, the ethnic status of the role models made no difference for any outcome variable. Ways to implement scientific knowledge into practice by providing research-based tools for multicultural education are discussed.
\end{abstract}

Keywords: school intervention, vicarious contact, ingroup role models, outgroup role models, adolescence, perceived norms 


\section{A teacher-led vicarious contact intervention in culturally mixed classrooms with in- and outgroup role models of intergroup friendship}

Schools are in many European countries becoming more and more ethnically and culturally diverse and thus face the need to find ways to support the development of positive intergroup relations among children and adolescents. This has also more far-reaching consequences, as schools provide an essential platform for affecting the attitudinal climate of the society in the future (Vedder, Horenczyk, Liebkind, \& Nickmans, 2006). The task of supporting positive outgroup attitudes lies heavily on the shoulders of teachers, who are critical agents of social change. To succeed in this task, scientifically based tools and practices that can help teachers to promote and maintain positive intergroup relations among students from culturally diverse backgrounds are on demand.

Despite this urgent need for equipping the teachers with research-based prejudicereduction techniques, interventions conducted in schools are still mostly carried out by

researchers themselves (Ülger, Dette-Hagenmeyer, Reichle, \& Gaertner, 2018). An encouraging exception is the Friendship Project by Turner and Brown (2008), in which the researchers advised the teachers to base their classes on lesson plans provided in the resource pack developed by the researchers. In addition, despite the increasing diversity in schools, most prejudice-reduction interventions have been targeted towards majority students only (e.g., Cameron, Rutland, Brown, \& Douch, 2006; Stathi, Cameron, Hartley, \& Bradford, 2014; Vezzali, Stathi, \& Giovannini, 2012). There are only a couple of examples of school interventions that have aimed to improve intergroup attitudes among adolescents and targeted all students in culturally mixed classrooms (Liebkind, Mähönen, Solares, Solheim, \& JasinskajaLahti, 2014; Houlette et al., 2004). 
The current study continues the research conducted by Liebkind and her colleagues $(2014 ; 2019)$ and aims to test the effectiveness of the prejudice-reduction intervention delivered by teachers in a real school setting including both minority and majority students.

\section{Promoting positive intergroup relations in schools}

The bulk of social psychological research on improving intergroup relations is based on the beneficial consequences of direct intergroup contact as conceptualized in the contact hypothesis (Allport, 1954), which states that, under certain conditions, contact with an outgroup member improves outgroup attitudes. These conditions include equal status between persons engaging in intergroup contact, cooperation through which common goals are to be achieved, and institutional support for contact offered by the authorities concerned. As pointed out by Turner and Cameron (2016), these conditions are often present in culturally diverse classrooms as students of the same age are encouraged by their teachers to co-operate on their school tasks. In addition, culturally diverse classrooms can provide opportunities for the development of intergroup friendships, a supplementary precondition for successful intergroup contact (Pettigrew, 1998).

Although the school setting provides, at least theoretically, opportunity and optimal preconditions for positive intergroup contact to take place, ethnic and cultural diversity in the classroom is in and of itself not necessarily enough to promote intergroup friendships and improve ethnic attitudes among students (Dixon, Tredoux, Durrheim, Finchilescu, \& Clack, 2008; Thijs \& Verkuyten, 2014). The opportunity may not be pursued, as students may selfsegregate by preferring to interact with their ingroup peers outside the classroom setting (Al Ramiah, Schmid, Hewstone, \& Floe, 2015; Dixon et al., 2008). For example, in their intervention study among first and second grade children in the United States, Houlette and colleagues (2004) 
noticed that even in well integrated classrooms, children still had a general preference for playing and sharing with children who were racially similar to themselves over children who were racially different. Furthermore, ethnic diversity in schools may even result in negative outgroup attitudes among both majority and minority youths (Vervoort, Ron, Scholte, \& Scheepers, 2011).

Given that mere opportunities for intergroup contact in the school environment might not be enough for actual intergroup contact to take place, actions for promoting positive intergroup encounters among students are needed. Interventions utilizing direct contact are shown to be effective in improving intergroup attitudes (Beelmann \& Heinemann, 2014; Paluck \& Green, 2009; Paluck, Green, \& Green, 2018), although it should be noted that contact effects are often weaker among minority than majority students (Binder et al., 2009). Furthermore, school interventions relying on direct intergroup contact can be challenging to implement, as it might be difficult to ensure or create positive face-to-face intergroup contact experiences for each student in the classroom. If this fails, the contact experience could be superficial or negative instead of positive, with concomitant consequences for intergroup attitudes (Barlow et al., 2012). Thus, external facilitators, like researchers or other volunteers may be needed to carry out interventions utilizing direct contact. For example, in a successful intervention study by Berger, Benatov, AbuRaiya, and Tadmor (2016), Israeli-Palestinian and Israeli-Jewish facilitators with expertise in working with youths in multicultural contexts facilitated the direct contact between IsraeliPalestinian and Israeli-Jewish students from different schools.

However, according to previous studies, direct face-to-face contact is not the only way to improve intergroup relations, as prejudice can be reduced also by imagining (Crisp \& Turner, 2009), knowing about (Wright, Aron, McLaughlin-Volpe, \& Ropp, 1997) or observing 
(Mazziotta, Mummendey, \& Wright, 2011) positive interaction between members of the in- and outgroup. According to meta-analyses (Beelmann \& Heinemann, 2014; Paluck \& Green, 2009), different forms of indirect contact might not yield as strong effects as direct intergroup contact, but they have been shown to be equally effective for both majority and minority members (Vezzali, Hewstone, Capozza, Giovannini, \& Wölfer, 2014) and may support or add to natural direct intergroup contact experiences in the future (Brown \& Paterson, 2016). They may also provide the possibility for more structured and controlled interventions for teachers to implement by themselves. For example, in interventions utilizing indirect contact through written stories, the valence of the contact can be manipulated and controlled beforehand.

\section{Improving ethnic attitudes through vicarious contact}

Some researchers have emphasized the distinction between merely knowing that ingroup friends have outgroup friends and observing intergroup contact between members of the in- and outgroup - the former type of indirect contact referring to extended contact and the latter to vicarious contact (Dovidio, Eller, \& Hewstone, 2011; Vezzali et al., 2014). Extended contact is often operationalized by asking people about the prevalence of direct outgroup contact and friendships among their friends (e.g., Turner, Hewstone, \& Voci, 2007; Visintin, Brylka, Green, Mähönen, \& Jasinskaja-Lahti, 2016). Vicarious contact, in turn, is most often studied experimentally so that the intergroup contact that is being observed is manipulated (Vezzali et al., 2014). This can be achieved by using narratives of intergroup contact experiences that are presented, for example, through reading stories (e.g., Cameron \& Rutland, 2006; Liebkind et al., 2014) or watching audiovisual media (e.g., Mazziotta et al., 2011; Schiappa, Gregg, \& Hewes, 2005; see also Joyce \& Harwood, 2014). 
The positive effect of indirect vicarious contact on outgroup attitudes is assumed to rest on observing role models having a successful cross-group interaction which implies that ingroup members are positively inclined towards the outgroup - and vice versa (Vezzali et al., 2014). Thus, vicarious contact follows the principles included in the theory of social learning (Bandura, 1986), which states that through observing others, we adopt social norms and learn codes of conduct on how to behave in similar situations. Based as it is on social learning, it is in vicarious contact important that the role models are perceived as persons one can identify with. For example, Vezzali, Stathi, Giovannini, Capozza, and Trifiletti (2015a) found in their study that reading excerpts from Harry Potter books dealing with prejudice towards fantasy outgroups improved the outgroup attitudes towards real stigmatized groups only among those participants who identified highly with the main character. Also the extended contact hypothesis (Wright et al., 1997) suggests that the effect of indirect contact should be stronger with the observation of similar (vs. dissimilar) others, who are more likely to be relevant anchors against which to compare oneself. In addition, the role models of intergroup contact need to be perceived as typical representatives of their ingroups, as the generalization of the positive attitude elicited by vicarious contact is dependent on the salience of the group memberships of the role models (Hewstone \& Brown, 1986). For example, in the vicarious contact intervention by Liebkind and colleagues (2014), perceived prototypicality of in-group and out-group peer models in the written stories of intergroup friendship and attitude change contributed positively to intervention effects.

Given the importance of the possibility to identify with the positive role models in the intervention, it is surprising that the bulk of previously implemented intervention studies have not taken into account the need to provide role models that as many students as possible can 
identify with. Yet it would be important for vicarious contact school interventions to include ingroup role models for all students and not rely only on majority role models, who tell about their positive contact experiences with minority group members. Moreover, the vicarious contact experiences should ideally be presented in first-person voice, as this has been shown to create a more immediate sense of closeness and familiarity to the main character and thus be more conducive to experience-taking than third-person narratives (Kaufman \& Libby, 2012). Hence, stories written in first-person voice that depict characters who share a relevant group membership with readers should be most effective in bridging the psychological gap between the reader and the narrator (Kaufman \& Libby, 2012).

\section{The present study}

In this study, we aimed to test the effectiveness of a vicarious contact intervention among both ethnic majority and minority adolescents and explore the role of majority and minority (i.e., in- and outgroup) role models in the effect of vicarious intergroup contact. ${ }^{1}$ In addition, as more efforts are needed to develop intervention tools that are available and feasible for schools, the intervention sessions were carried out by teachers. Outgroup attitudes as well as perceived ingroup and outgroup norms regarding outgroup attitudes and intergroup contact were studied as outcomes, as all of these have been found to be indicative of prevailing intergroup relations and reactive to indirect intergroup contact (Vezzali et al., 2014). Especially when studying intergroup relations among adolescents, it is important to investigate not only attitudes but also perceived norms, as social conformity becomes increasingly salient in adolescence and adolescents are

\footnotetext{
${ }^{1}$ This study was part of a larger project on vicarious contact as a tool for prejudice-reduction in schools. In this article, we present results based on previously un-published data. For previous studies on developing the intervention and assessing its effectiveness as a teacher-led intervention, please see Liebkind et al. (2014; 2019).
} 
found to be sensitive to messages from their peer network (Brown \& Larson, 2009; McGuire, Rutland, \& Nesdale, 2015; Özdemir, Sun, Korol, Özdemir, \& Stattin, 2018). Moreover, indirect contact has been shown to increase the salience of positive norms and positive intergroup attitudes among peers (Vezzali et al., 2014), which further mediates the effects of indirect contact on outgroup attitudes (Vezzali, Stathi, Giovannini, Capozza, \& Visintin, 2015b; Cameron, Rutland, Hossain, \& Petley, 2011). Thus, focusing on outgroup attitudes and perceived norms is equally important.

The intervention method of behavioural journalism (see, e.g., Liebkind \& McAlister, 1999) was implemented using written first-person narratives of intergroup friendship told by peer models of the same age. Based on the social learning perspective, these stories acted as channels for communicating social norms regarding intergroup contact, describing what peers do and therefore what the reader should do (Bandura, 1986). The storytellers represented either ethnic majority, or ethnic minority adolescents, who told how they have met and become friends with youth from a different cultural group, and how this contact has eventually changed their attitudes toward this particular group. Through these stories, both majority and minority adolescents observed positive cross-group interaction vicariously. This is important, as previous research has shown that the effect of indirect contact builds on identification with the ingroup member having an outgroup friend, and that indirect contact is effective for both majority and minority members (Vezzali et al., 2014). However, until now, the independent effects of in- and outgroup role models of vicarious contact have been studied neither among majority nor minority members in a naturalistic setting. Previous research has corroborated the evidence for improved outgroup attitudes through positive outgroup role models, who are experienced as relatively prototypical of the outgroup (McIntyre, Paolini, \& Hewstone, 2016; see also Mastro \& Tukachinsky, 2011) or 
who are perceived to favour contact with the ingroup (Olsson, Matera, Tip, \& Brown, 2017), but to our knowledge, this has not been studied in field experiments.

To assess the effect of the ethnic status of the role model, the design of the intervention study included two experimental groups, which differed based on the order of presentation of stories with majority or minority storytellers. In other words, half of the participants were first exposed to stories with majority storytellers, while the other half was first presented with stories told by minority storytellers. These storytellers represented either in- or outgroup role models depending on the participant's own ethnic status. This allowed us to study if there is an effect of the ethnic status of a storyteller on the effect of vicarious contact during the first follow-up assessment (cf. the Methods section below). Our first research question was: Is the effect of vicarious contact on a) outgroup attitudes, b) ingroup norms, and c) outgroup norms different depending on the ingroup or outgroup membership of the role models? We only explored this question, as it has not been studied before in any real-life interventions.

After first presenting the students with either minority or majority storytellers, the design of the field experiment continued with a similar set of intervention sessions but by changing the ethnic status of the storytellers, i.e., those presented before with minority storytellers were presented with majority storytellers, and vice versa. Thus, students in both experimental groups had eventually participated in the same larger intervention and were subjected to all the friendship stories. This procedure enabled us to use the whole experimental group to test the overall effectiveness of an intervention, which included both ingroup and outgroup storytellers (although presented in different order). Our second research question was: Is there a vicarious contact effect on a) outgroup attitudes, b) perceived ingroup norms, and c) perceived outgroup norms? We expected that both majority and minority adolescents in the experimental conditions 
would display more positive attitudes towards outgroup members and perceive both in- and outgroup norms as more positive as a result of the intervention.

\section{Context of the study}

Compared to many Western countries, Finland is characterized by a relatively low proportion of immigrants. Although a change is notable as the number of foreign-language speakers has increased almost five-fold in the past two decades, still only around 6 percent of the population speaks a foreign language as their mother tongue (Statistics Finland, 2017). There is, however, much variation in ethnic diversity between different regions of the country. The number of foreign-language speakers is highest in the capital area and especially in the municipality of Vantaa, where the data for the present study was collected. In the year of data collection, 15.8 percent of the inhabitants in the municipality spoke a foreign language as their mother tongue (City of Helsinki Urban Facts, 2017).

\section{Method}

\section{Participants}

Participants were students of the 7th and 8th grades in secondary school. Out of 1056 students who were invited to take part in the study, 915 participated by completing baselines assessment. After excluding participants who took part only in the baseline assessment $(n=109)$ or did not participate in both later waves $(n=223)$, the final sample consisted of 583 students $\left(51.4 \%\right.$ girls; $M_{\mathrm{age}}=13.4$ years, $\left.S D=.56\right)$. The students who dropped out after the baseline assessment or at later stages did not differ from the students in the final sample regarding gender $\left(\chi^{2}(1)=.04, p=.852\right)$, majority/minority status $\left(\chi^{2}(1)=.15, p=.698\right)$ or research condition $\left(\chi^{2}(1)=.99, p=.320\right)$, but 8 th graders were more likely to drop-out than 7 th graders $\left(\chi^{2}(1)=\right.$ $19.94, p<.001)$. Furthermore, there were no differences regarding outgroup attitudes $(t(898)=-$ 
$.46, p=.645)$, perceived ingroup norms $(t(883)=-1.30, p=.195)$, or perceived outgroup norms $(t(890)=-.27, p=.784)$.

In the final sample, 75.8 percent were majority Finns $\left(n=437 ; 49.4 \%\right.$ girls; $M_{\text {age }}=13.38$ years, $S D=.52$ ) whose both parents were born in Finland. The rest of the participants had at least one foreign-born parent and were thus classified as belonging to the minority sample of this study $\left(n=146 ; 55.5 \%\right.$ girls; $M_{\text {age }}=13.54$ years, $\left.S D=.66\right)$. Most of them were secondgeneration immigrants (i.e., born in Finland; 70.5\%) and had both parents born outside Finland $(60.3 \%)$. Parents born in Europe $(50 \%)$ were mostly from Estonia and Russia, parents born in Asia (19\%) were mostly from Thailand and Vietnam, parents born in Africa (18\%) were mostly from Somalia, and parents born in the Middle East (12\%) were mostly from Turkey and Iraq.

\section{Procedure}

Permission for the study was obtained from the school board of the municipality and the intervention program was introduced to all 16 Finnish-language secondary schools in the municipality during spring 2016. As the study was to be carried out by the teaching staff, thus demanding time and effort from schools, expectedly many schools could not fit the study into their curriculum. Altogether six schools were willing to participate in the study and these schools were divided into control and experimental conditions by considering their possibilities to implement the intervention sessions between September and November 2016. We made the choice not to allocate classes within the same schools into different conditions in order to prevent any possible spill-over effects between conditions (cf. Liebkind et al., 2014). Four schools were assigned to the experimental condition. To answer our first research question (i.e., whether there is an effect of the ethnic status of the storyteller), the experimental schools were further divided into two experimental sub-groups. In order to make the samples allocated to these sub-groups 
demographically as similar as possible, we considered the size of the schools, percentage of students with immigrant background and the socio-economic status of the school districts (employment rate and percentage of foreign-language speaking residents).

With the approval of the principals, the intervention sessions were implemented as part of the schools' curricula and the sessions were held by the teaching staff, mainly study counselors. The intervention consisted of altogether four 45-minute sessions that were delivered in two sets, which differed in terms of the ethnic status of storytellers. Namely, for one experimental group, stories with ethnic majority storytellers were presented in the first set and those with ethnic minority storytellers in the second set, while the order was reversed in the other experimental group (see Table 1). Instead of having two distinct experimental groups with only majority or minority storytellers, this procedure was chosen in order to expose all participants with the viewpoints of both majority and minority role models, which is ecologically more valid and culturally sensitive considering the culturally mixed classrooms.

The intervention was assessed through three rounds of questionnaires (see Table 1) for which the parental consent for participation was sought as all the participants were minors. Participants filled in the electronic questionnaires in the classrooms under the supervision of a teacher who received written instructions on how to arrange the situation. To prevent students in the experimental groups from linking the questionnaires to the intervention sessions, the teachers who held the sessions were not involved in the assessments, except in one school, in which assessments were not possible to allocate to another teacher. For the final third assessment, research assistants were sent to the schools in order to reduce participant fatigue and drop-out in the last assessment.

\section{INSERT TABLE 1 HERE}




\section{Implementation of the intervention}

Teachers carried out the sessions according to a teacher's manual which was composed of two parts. The first part focused on giving background information on intergroup attitudes and explaining the theoretical background of interventions relying on vicarious contact. This information was given to the teachers in order to strengthen their understanding of the aims and means of the intervention. However, it was emphasized that running the sessions does not require any prior expertise, as the information the teachers were to give to the students regarding, for example, outgroup attitudes, was ready formulated for the teachers in the second part of the manual, which contained detailed instructions and indicated time frames for every session. The teacher's manual was adapted separately to each of the two experimental groups and teachers were not aware of the other experimental group.

Even though the teachers' manual was written in as detailed a manner as possible to enable its independent use, the teachers were in addition given a brief training by the first author in order to strengthen their fidelity to the instructions given in the manual and to assure that they were aware of the most important aspects of the sessions. For example, the importance of maintaining a positive, encouraging atmosphere throughout the sessions and of not allowing racist comments was emphasized. If negative experiences (e.g., discrimination) were brought up by the students, the teachers were instructed to briefly acknowledge them but pass them over in a subtle way by noting that the session's focus is on positive experiences. Importantly, the teachers were also instructed not to call attention to individual students' group affiliations in class, as ethnic categories imposed by the teacher might not be valid for the students themselves. It was, however, only the students' own group membership that was not emphasized. In the intervention material, group salience was imperative, because the intervention method relies on salient group 
memberships, as only that salience enables positive attitudes towards individual outgroup members to be generalized to the outgroup as a whole (Hewstone \& Brown, 1986; Wright et al., 1997).

\section{"Stories about friendship" intervention sessions}

The core of the sessions was built on altogether 12 friendship stories in which storytellers communicated how they have met and become friends with someone from the ethnic outgroup. All of the stories followed the same basic plot in which the storyteller told about her/his initial apprehensions towards people from the outgroup and how this apprehension disappeared through getting to know a youth from the outgroup (cf. Appendix). The stories were created for an intervention study by Liebkind and colleagues (2014) after pilot interviews with Finnish and immigrant youths. For the present study, these stories were slightly modified, for instance by toning down the initial prejudice and apprehensions in the beginning of the stories, making storytellers communicate initially only subtle uneasiness and unfamiliarity with the outgroup members. The storytellers were both boys and girls and both majority Finns and youths with an immigrant background. The ethnicity of the storytellers with immigrant background as well as the ethnicity of the outgroup friends in the stories told by majority Finns represented the most typical immigrant groups in the Finnish society (e.g., Russians, Estonians, Somalians). All stories included also a picture and the name of the youth telling the story as well as some personal information about the role models (e.g., hobbies, preferences and/or family relations).

Apart from the ethnic status of the storytellers, the two sets of sessions were identical. The first session started with an introduction including a brief presentation of relevant key concepts of the sessions (e.g., attitudes, prejudice) which the teacher delivered according to the instructions provided in the teachers' manual. During every session, new friendship stories were 
projected to the screen in the classroom and read aloud by voluntary students. In the first session, teachers were instructed to draw students' attention to the essential points of the stories by asking the students how the thoughts of the youth in the story changed, what facilitated the change, and what positive consequences this had for the storyteller. In order to avoid repetition, students were after reading the friendship stories in the second session asked to recall their own similar positive intergroup encounters. These intervention elements were to some extent similar to those presented in the teacher's manual (Solares, Huttunen, Mähönen, Hirvonen, \& Liebkind, 2012) used in the intervention studies by Liebkind and colleagues $(2014 ; 2019)$.

As a new intervention element, students were in both sets of the sessions allocated into small groups and given the task of creating and filming a video blog of about two minutes in which they portrayed a friendship story similar to those presented during the sessions. The video blogs were created from the viewpoint of a youth belonging either to ethnic majority or minority group, depending on the type of the session. Even though the stories in the video blogs were allowed to be fictional, students were encouraged to utilize their own positive intergroup contact experiences in making the video blog together. In this way, the students acted as additional senders of a positive social norm regarding intergroup contact. The video blogs were watched together in class and students were asked to vote for the best video. In order to enhance the students' commitment to the task, a lottery of movie tickets was held for the winners of the video blog assignment from all schools in the experimental groups.

\section{Measures}

As the participants were both majority and minority members, the target outgroup addressed in the measures was dependent on the respondents' own ethnic status. For the majority participants, the target outgroup was people with a foreign background (at least one foreign-born 
parent) and for the minority participants the outgroup was Finnish people whose background is only Finnish (both parents born in Finland). However, for ethical reasons, in the beginning of the questionnaire, participants were explicitly told that the division into Finns and people with foreign background was made only for the sake of simplicity, as also people with a foreign background can be regarded as Finnish.

Outgroup attitudes were assessed by asking the participants to indicate their overall feeling towards outgroup members on a single-item 'feeling thermometer' (Haddock, Zanna, \& Esses, 1993) scaling from $0=$ feelings extremely cold to $100=$ feelings extremely warm.

Perceived in- and outgroup norms were assessed with a measure adapted from Turner, Voci, Hewstone, and Vonofakou (2008). The three-item measure regarding ingroup norms was asking participants to think about their own ingroup in general (i.e., people with the same cultural background) and what they would think about people with a foreign background/Finns. The measure included the items "In general, how much do you think they like Finns/people with a foreign background?" "Do you think they would be happy to spend time with Finns/people with a foreign background?", "Do you think they want to be close friends with Finns/people with a foreign background?" Response options ranged from $1=$ not at all to $5=$ very much. The sum variable was created only for those participants who responded to all three items (majority sample: T1 $\alpha=.84 ; \mathrm{T} 2 \alpha=.84 ; \mathrm{T} 3 \alpha=.88 /$ minority sample: T1 $\alpha=.85 ; \mathrm{T} 2 \alpha=.81 ; \mathrm{T} 3 \alpha=$ .85). Perceived outgroup norms were assessed by using the same three-item measure, but with reversed in- and outgroup positions (majority sample: T1 $\alpha=.80 ; \mathrm{T} 2 \alpha=.83 ; \mathrm{T} 3 \alpha=.87$ / minority sample: $\mathrm{T} 1 \alpha=.84 ; \mathrm{T} 2 \alpha=.86 ; \mathrm{T} 3 \alpha=.86$ )

Background information about prior direct contact experiences was also obtained. Quantity of direct contact with outgroup members was assessed by asking "How often do you 
spend time with people with foreign background/Finns? They can be, for example, friends, parents of your friends, or neighbors". Quality of direct contact was assessed by separately measuring the amount of negative and positive direct contact with two single-item measures adapted from Barlow and colleagues (2012): "How do you usually experience interaction with people with foreign background/Finns? How often do you experience interaction with them a) positive, b) negative? Participants responded to all measures regarding direct contact on scales from $1=$ never to $5=$ very often .

In addition to the main questionnaires, participants in the experimental groups filled in a short feedback questionnaire after both sets of the intervention sessions. As a manipulation check of the vicarious contact, perceived typicality of the role models was assessed by asking students how typical Finns/people with foreign background the storytellers were, and perceived similarity of self with storytellers was assessed by asking how much the students had in common with them. Both perceived typicality and perceived similarity were assessed using an eleven-point scale ranging from 0 to 100 .

\section{Analyses}

To examine the intervention effect on three dependent variables (outgroup attitudes and perceived in- and outgroup norms), 2 x 2 mixed design ANOVAs were conducted separately for the majority and minority samples. For testing the role of the storytellers' ethnic status for the effectiveness of the intervention (RQ1), the experimental sub-group (majority or minority storytellers during the first two sessions) was used as a between-subjects factor and time (dependent variable at T1 and T2) as within-subjects factor. In order to test the general effectiveness of the intervention (RQ2), the condition (experiment vs control) was used as a between-subjects factor and time (dependent variable at T1 and T3) as a within-subjects factor. 
As the participants were both $7^{\text {th }}$ and $8^{\text {th }}$ graders, grade was included in all analyses as a fixed factor and treated as a covariate. In addition, as gender differences have been reported in outgroup attitudes (e.g., Barrett, 2007; Liebkind \& McAlister, 1999) as well as in the effectiveness of a vicarious contact intervention (Liebkind et al., 2019), we also included gender as a covariate.

\section{Results}

\section{Descriptive results}

First, we examined the extent to which the storytellers were perceived to be typical majority and minority members and similar to the participants themselves. As seen in Table 2, both majority and minority participants perceived in- and outgroup storytellers to be relatively typical members of their groups (on average above the midpoint of a scale) and there were no differences between the ratings of the typicality of in- and outgroup storytellers. Perceived similarity of the self with the in- and outgroup storytellers, in turn, was rather low (on average under the midpoint of a scale) among both majority and minority participants and no differences between the ratings of the similarity with in- and outgroup storytellers were found. Independent samples $t$-tests were conducted in order examine the possible gender differences in the perceived typicality of the storytellers and their similarity with self. The results showed that in the majority sample, girls perceived majority storytellers to be more typical $(M=65.33 ; S D=19.09)$ than boys $\operatorname{did}(M=56.05 ; S D=22.34),(t(164)=2.89, p=.004)$ and, inversely, in the minority sample, boys perceived minority storytellers to be more typical $(M=67.59 ; S D=16.83)$ than girls did $(M=56.18 ; S D=23.36),(t(61)=-2.19, p=.032)$. Thus, it can be concluded that the intervention was not fully successful in creating an ideal setting for vicarious contact by 
providing role models that were on average perceived to be only relatively typical and somewhat similar to the self.

\section{INSERT TABLE 2 HERE}

As seen in Table 3, prior outgroup attitudes were relatively positive (on average above the midpoint on a scale from 0 to 100) in both control and experimental groups within both majority and minority samples. On average, participants also perceived in- and outgroup norms to be relatively positive before the intervention. As the division into research conditions was made at the school level, independent samples t-tests were used in order to determine whether there were any mean differences in the baseline (T1) values of the three dependent variables (outgroup attitudes, in- and outgroup norms) between control and experimental groups. The $t$ tests were performed separately for majority and minority samples. There were no differences in the baseline values in the minority sample, but in the majority sample, participants in the experimental condition had initially more positive outgroup attitudes when compared to the control condition $(t(433)=3.05, p=.002)$. In addition, when mean differences between the conditions were tested for prior direct contact experiences (quantity of prior contact and positive/negative quality of the contact), no differences between conditions were found.

Before conducting the main analyses, Intra-class Correlation Coefficients (ICC) were computed to estimate the proportion of variability in the dependent measures accounting for both school and class level. As seen in Table 3, for all three dependent measures ICCs indicated that not more than 4.1 percent of the shared variance occurred between schools and not more than 2.6 percent of the shared variance occurred between classrooms. For this reason, the nested data structure was disregarded, and multilevel models were not used for conducting the main analyses. 


\section{INSERT TABLE 3 HERE}

\section{Main analyses}

To assess the role of the storytellers' ethnic status in the effectiveness of the vicarious contact intervention (RQ1), we tested whether there were any differences in the mean changes among the two experimental sub-groups which differed in terms of whether the students were presented in the first set of sessions with stories told by majority or minority storytellers. The differences tested thus referred to changes between the pre-intervention (T1) assessment and the assessment at the midpoint of the intervention sessions (T2), as after T2 the ethnicity of the storytellers changed (see Table 1). Mixed design ANOVAs were conducted separately for the majority and minority samples and included two experimental sub-groups as between-subjects factors and time as a within-subject factor. Grade and gender were included as fixed factor covariates. As seen in Table 4, there were no differences between the two experimental subgroups, indicating that the ethnic status of the storyteller did not influence the vicarious contact effect.

In further exploratory analyses related to the first research question, we tested whether the typicality and similarity of the storytellers affected change in outgroup attitudes and in- and outgroup norms among majority and minority students. Thus, mixed design ANOVAs were re-run with perceived typicality and similarity added as moderators in separate analyses. Perceived similarity of self with the storytellers did not affect any dependent variable, but we found that the perceived typicality of the storytellers affected ingroup norms among majority participants $\left(F(1,132)=2.27, p=.032\right.$, partial $\left.\eta^{2}=.11\right)$. Surprisingly, however, majority students who perceived majority storytellers to be atypical, perceived ingroup norms to be more positive after the intervention $\left(M_{T 1}=2.88, S D_{T 1}=.87 ; M_{T 2}=3.32, S D_{T 2}=.91 ; t(25)=-3.19, p=\right.$ 
.004) when compared to those who perceived majority storytellers as typical members of their group $\left(M_{T 1}=3.10, S D_{T 1}=.73 ; M_{T 2}=3.00, S D_{T 2}=.77 ; t(37)=1.36, p=.183\right)$. Furthermore, when the majority students who perceived ingroup storytellers to be atypical were compared to the control group, the interaction effect of time and group on ingroup norms was significant $\left(F(1,212)=15.35, p<.001\right.$, partial $\left.\eta^{2}=.068\right)$. This indicates that the change observed among majority students who perceived ingroup storytellers to be atypical was not present in the control $\operatorname{group}\left(M_{T 1}=3.03, S D_{T 1}=.73 ; M_{T 2}=3.04, S D_{T 2}=.73 ; t(193)=-.31, p=.755\right)$.

\section{INSERT TABLE 4 HERE}

The overall effectiveness of the whole two-stage, 4-session intervention (RQ2) was assessed by performing mixed design ANOVAs separately for the majority and minority samples in order to test whether the mean changes in dependent measures between pre-intervention (T1) and post-intervention (T3) assessments were different in the experimental and control conditions. In the analyses, the condition (experiment vs control) was used as a between-subjects factor and time as a within-subjects factor. As in earlier analyses, the effects of grade and gender were controlled for.

The results showed that there was a significant interaction effect of condition and time on outgroup norms, but only in the minority sample $\left(F(1,124)=5.78, p=.018\right.$, partial $\left.\eta^{2}=.045\right)$. As seen from the means provided in Table 5, after the intervention students with an immigrant background perceived majority Finns to have more positive attitudes towards immigrants than before the intervention. On the other hand, perception of norms prevailing in the ingroup were not influenced by the intervention, neither among minority nor majority participants. Regarding outgroup attitudes, there was a significant interaction effect of condition and time in the majority sample only $\left(F(1,415)=5.99, p=.015\right.$, partial $\left.\eta^{2}=.014\right)$. Unexpectedly, however, this effect on 
outgroup attitudes turned out to be in favor of the control group: the attitudes of the Finnish majority students in the experimental condition did not change, whereas they slightly improved in the control condition. Thus, the hypothesis regarding the RQ2 was only partly supported, and it should be noted that the effect sizes of both interactions were rather small.

\section{INSERT TABLE 5 HERE}

\section{Discussion}

Previous anti-prejudice interventions implemented in schools have been for the most part conducted by researchers instead of the schools' teaching staff, and even rarer are attempts to simultaneously engage all students in culturally heterogeneous classes in such interventions (Ülger et al., 2018). As teachers need to respond to the growing ethnic and cultural diversity in classrooms on an everyday basis, efforts should be made to find research-based solutions that acknowledge both majority and minority students and are practicable enough to be used in naturalistic settings without the need of researchers or other external facilitators to carry out the intervention. The current study aimed to fill both of these gaps by testing the effectiveness of a teacher-led prejudice-reduction intervention among both minority and minority adolescents and by exploring, to our knowledge for the first time, the effect of the ethnic status of the role models in a vicarious contact intervention.

When assessing the effectiveness of the intervention as a whole (T1-T3), there was no positive intervention effect on outgroup attitudes or perceived in- and outgroup norms among majority students, but the intervention improved perceived outgroup norms among minority participants. Despite these different intervention effects obtained among majority and minority participants, however, the ethnic status of the storyteller did not influence the effectiveness of the intervention on any of the outcome variables tested, neither among majority nor among minority 
participants. However, if the perceived typicality of the storytellers was taken into account when assessing the effect of the in- and outgroup storytellers in the first stage of the intervention (T1T2), the results showed that the ingroup norms of the majority students improved among those who perceived ingroup storytellers to be atypical of their group.

This latter finding is interesting as it is counter to theory, according to which it could be anticipated that only typical role models would have an impact on how norms among other group members are perceived (e.g., Wright et al., 1997). However, this finding is not necessarily counter-intuitive. It might be that the ingroup norms perceived by majority participants to be on average only moderately positive before the intervention could have appeared to be more positive only when the role models were considered as atypical members of the ingroup, thus setting a surprising example that exceeded the previous perception of concomitant attitudes among fellow ingroup members. This could have set a new standard of comparison against which perceptions of the entire ingroup was re-evaluated in a more positive direction (see e.g., Harwood et al., 2017). Although we can only speculate what made some majority students perceive the ingroup role models as atypical representatives of their group, one possible explanation is that it was the growth stories, in which storytellers communicate how their initial prejudice has changed, that triggered this re-evaluation of ingroup norms.

Regarding the effectiveness of the overall intervention (T1-T3), the results obtained in the current study are partly contradictory to recent meta-analyses (Beelmann \& Heineman, 2014; Ülger et al., 2018), which have concluded that the effects of prejudice-reduction interventions are weaker for minority members than for majority members. Our results indicate the opposite, as the overall intervention influenced ethnic minority members' perception of outgroup norms, i.e., of social norms prevailing in the national majority group, while no similar effect could be 
discerned in the majority students' perceptions of outgroup norms prevailing among immigrants. One reason for this difference between the majority and minority participants might be that for the minority students, the majority storytellers constituted a single well-defined outgroup, whose norms they were able to observe through the friendship stories. This observation might have been more likely to generalize to all outgroup members than the observations made by the majority participants, for whom the outgroup storytellers represented six different ethnic backgrounds, some of them being culturally very close (e.g., Estonian and Russian storytellers) and others more culturally distant (e.g., Somalian and Iraqi storytellers). Furthermore, the improved outgroup norms among minority, but not among majority students could also be explained by the minority youth's previous experiences of being discriminated by the majority group. For them, the friendship stories (or classmates' possible positive reactions to them) might have offered an especially positive and thus more powerful example of the norms prevailing in the majority group that contradicted their earlier experiences.

Unlike many other intervention studies on extended and vicarious contact (e.g., Vezzali et al., 2012; Cameron \& Rutland, 2006), we did not obtain any direct effects of the intervention on outgroup attitudes. Quite to the contrary, we obtained an unexpected result: the attitudes of the Finnish majority students remained unchanged in the experimental conditions, while they improved in the control condition. The reason for this unanticipated result might be the initial difference in intergroup attitudes between the control group on the one hand and the experimental group on the other: the intergroup attitudes in the experimental group were relatively more positive before the intervention than the initial attitudes in the control group. Positive prior outgroup attitudes might have resulted in a ceiling effect among students in the experimental group, as it is not realistic to expect to improve attitudes that are already on average 
relatively positive. Previous research gives support for this conclusion, as people with negative intergroup attitudes to begin with benefit more from direct and indirect intergroup contact (Hodson, Costello, \& MacInnis, 2013, Liebkind et al., 2019).

Although our intervention was not able to affect the intergroup attitudes of majority or minority adolescents directly, improvement in the perceptions of social norms is equally important, as both ingroup and outgroup norms have been shown to mediate the effects of indirect contact on outgroup attitudes (Cameron et al., 2011; Vezzali et al., 2015b). It is possible that the improved outgroup norms found among the minority students could have an effect on their intergroup attitudes, for example, by leading to increased willingness for intergroup contact and thus to formation of new outgroup friendships at a later stage after the intervention (see Vezzali et al., 2015b). For example, Olsson and colleagues (2017) recently showed that outgroup members who were perceived to favour intergroup contact elicited more positive outgroup attitudes. However, we can only speculate on this possible multiplicative effect as this study did not include further follow-ups.

The relatively weak intervention effects obtained in this study call for thorough consideration of possible reasons for this. In the light of meta-analytical findings, one possible reason for the modest success of this particular field experiment might be its strict focus on one intervention method, as integrative intervention programs combining multiple theories and intervention elements have had stronger and more generalized effects (Beelmann \& Heinemann, 2014). Another reason could be the relatively short duration of the intervention, as multiplesession interventions are shown to be more effective for improving outgroup attitudes (Ülger et al., 2018). Especially when assessing the role of the in- and outgroup storytellers in the first stage of the intervention (T1-T2), only two sessions might simply not be enough to elicit any effects. It 
should also be noted that we were not fully successful in creating an ideal setting for vicarious contact, as perceived similarity of the self with the storytellers was, on average, only moderately high among both majority and minority students. This could be one explanation for the modest results obtained, speaking for the importance of careful implementation of the theoretical ideas on which vicarious contact interventions are based (Vezzali et al., 2015a; Wright et al., 1997). In addition, one reason for the lack of intervention effects may also be the teacher-led nature of this intervention, as previous interventions have rarely been implemented by teachers, and when they have, the effects of the interventions have in general been nonsignificant (Ülger et al., 2018). As pointed out by Ülger and colleagues (2018), this may be related to the low implementation fidelity of the interventions, as teachers who are mostly unfamiliar with the theoretical background of the intervention method may not follow the procedure of the intervention as accurately as intended. In this study, implementation fidelity was taken into consideration when designing the intervention by making the teachers' manual for the intervention sessions as detailed and structured as possible and by providing the teachers with a short training before intervention. However, one shortcoming of this study is that it did not include any measure for implementation fidelity, which makes it impossible to draw any further conclusions regarding the actual implementation of the intervention or its implications for the effectiveness of the intervention. Apparently, the role of the teacher conducting the interventions needs to be addressed more in depth in future research. One important aspect is to identify and find ways to overcome different implementation barriers that teachers might face when conducting intervention sessions (Long et al., 2016).

\section{Limitations}


The main limitation of the current study concerns the quasi-experimental study design, as the division into research conditions was made at the school level instead of allocating classes within the same schools into different conditions. This was done in order to prevent any possible spill-over effects between experimental and control groups (cf. Liebkind et al., 2014) and also to avoid teachers being aware of different experimental sub-groups, which could have led them to prefer one condition over the other, thus affecting the implementation of the intervention. Possibly due to this lack of sufficient randomization of students into the different conditions, there were baseline differences between the control and experimental groups in the outgroup attitudes among majority participants. Furthermore, it needs to be noted that even though we measured direct contact experiences prior to the intervention and did not obtain any differences between conditions, also other background factors could have influenced the findings of the current study. Alternatively, different condition groups may have been exposed to different external influences during the time of the study, which needs to be taken into account when interpreting the results.

Furthermore, it is possible that the schools volunteering for the study differed from those that did not. As pointed out by Verkuyten and Thijs (2013), the effectiveness of anti-prejudice actions in schools may be dependent on characteristics of the school context. Schools participating in our study, and especially those volunteering for the experimental group, may, for example, on average put more emphasis on anti-discriminatory education - either in a proactive manner or due to present needs. This may be one reason for our finding that intergroup attitudes in the experimental group were relatively more positive before the intervention than the initial attitudes in the control group. Future research on prejudice reduction interventions implemented in naturalistic educational settings should thus explore further the characteristics of the school 
context behind the intervention setting, for example, the general attitudinal climate of the school/classroom or the students' perceptions of the teachers' interest in carrying out the intervention sessions.

Finally, it needs to be noted that Finland may represent an unusual context for prejudicereduction interventions in that it can be regarded as relatively culturally homogeneous when compared to many other Western countries. As noted by Pettigrew (2018), disparate contexts of experimental studies can easily lead to differential results; studies done in one country may not replicate in another because of cultural and demographic differences between the two. This may be especially true of field experiments. Thus, more comparative research is needed in the future in order to disentangle the effects of socio-cultural context on the effectiveness of teacher-led prejudice-reduction interventions.

\section{Conclusions}

Efficient and practicable anti-discriminatory practices are vital in present-day as well as future multicultural educational settings. With our research we wanted to add to the knowledge on such practices and shed light on the importance of developing teacher-led prejudice-reduction interventions that could be transferable to actual use in schools. Despite the modest intervention effects obtained in this study, it is of great importance to report in detail what works - and what does not work - in prejudice-reduction interventions implemented by teachers, as only by doing that can we hope to develop prejudice-reduction interventions which work in practice. When taking into consideration the small number of previous studies addressing this issue (see Ülger et al., 2018), further efforts should be made in this regard - preferably in close collaboration with "grass-root level" practitioners in order to identify the possible barriers obstructing the effectiveness of teacher-led interventions. Therefore, we call for future studies addressing all 
students in class regardless of their cultural background, because, as our results indicate, the outcomes of the interventions are not necessarily the same for majority and minority participants. Addressing minority and majority students alike in prejudice-reduction interventions is especially important in heterogeneous classes, where students with minority background, and not only those with a majority background, need to be presented as first-person narrators of and active agents in intergroup contact, not just as targets of majority members' intergroup attitudes or as parts of majority members' experiences of intergroup contact.

\section{Acknowledgements}

We would like to thank Anna Seppänen for her help in data collection and coding, and other assistants for their help in the data collection. We would also like to express our appreciation for the $7^{\text {th }}$ and $8^{\text {th }}$ grade students, teachers and study counsellors who participated in this study. This work was supported by the European Social Fund [Grant number S20320]. 


\section{References}

Allport, G. W. (1954). The nature of prejudice. Reading, MA: Addison-Wesley.

Al Ramiah, A. A., Schmid, K., Hewstone, M., \& Floe, C. (2015). Why are all the White (Asian) kids sitting together in the cafeteria? Resegregation and the role of intergroup attributions and norms. British Journal of Social Psychology, 54, 100-124. https://doi.org/10.1111/bjso.12064.

Bandura, A. (1986). Social foundations of thought and action in social cognitive theory. Englewood Cliss, NJ: Prentice Hall.

Barlow, F. K., Paolini, S., Pedersen, A., Hornsey, M. J., Radke, H. R. M., Harwood, J., Rubin, M. \& Sibley, C. G. (2012). The contact caveat: Negative contact predicts increased prejudice more than positive contact predicts reduced prejudice. Personality and Social Psychology Bulletin, 38, 1629-1643. https://doi.org/10.1177/0146167212457953.

Barrett, M. (2007). Children's knowledge, beliefs and feelings about nations and national groups. New York, NY: Psychology Press.

Binder, J., Zagefka, H., Brown, R., Funke, F., Kessler, T., Mummendey, A., Maquil, A., Demoulin, S., \& Leyens, J-P. (2009). Does contact reduce prejudice or does prejudice reduce contact? A longitudinal test of the contact hypothesis among majority and minority groups in three European countries. Journal of Personality and Social Psychology, 96, 843-856. http://dx.doi.org/10.1037/a0013470.

Beelmann, A., \& Heinemann, K. S. (2014). Preventing prejudice and improving intergroup attitudes: A meta-analysis of child and adolescent training programs. Journal of Applied Developmental Psychology, 35, 10-24. https://doi.org/10.1016/j.appdev.2013.11.002. 
Berger, R., Benatov, J., Abu-Raiya, H., \& Tadmor, C. T. (2016). Reducing prejudice and promoting positive intergroup attitudes among elementary-school children in the context of the Israeli-Palestinian conflict. Journal of School Psychology, 57, 53-72. https://doi.org/10.1016/j.jsp.2016.04.003.

Brown, B. B., \& Larson, J. (2009). Peer relationships in adolescence. In R. M. Lerner \& L. Steinberg (Eds.), Handbook of adolescent psychology (3rd ed., pp. 74-103). Hoboken, NJ: Wiley.

Brown, R. \& Paterson, J. (2016). Indirect contact and prejudice reduction: Limits and possibilities. Current Opinion in Psychology, 11, 20-24. https://doi.org/10.1016/j.copsyc.2016.03.005.

Cameron, L., \& Rutland, A. (2006). Extended contact through story reading in school: Reducing children's prejudice toward the disabled. Journal of Social Issues, 62, 469-488. https://doi.org/10.1111/j.1540-4560.2006.00469.x.

Cameron, L., Rutland, A., Brown, R., \& Douch, R. (2006). Changing children's intergroup attitudes toward refugees: Testing different models of extended contact. Child Development, 77, 1208-1219. https://doi.org/10.1111/j.1467-8624.2006.00929.x.

Cameron, L., Rutland, A., Hossain, R., \& Petley, R. (2011). When and why does extended contact work? The role of high quality direct contact and group norms in the development of positive ethnic intergroup attitudes amongst children. Group Processes and Intergroup Relations, 14, 193-206. https://doi.org/10.1177/1368430210390535.

City of Helsinki Urban Facts (2017). Helsingin ulkomaalaistaustainen väestö vuonna 2016 (Population with foreign background in Helsinki 2016). City of Helsinki Urban Facts, 
Statistics 2017:1. Retrieved from www.hel.fi/hel2/tietokeskus/julkaisut/pdf/17_01_16_Tilastoja_2_Hiekkavuo.pdf

Crisp, R. J., \& Turner, R. N. (2009). Can imagined interactions produce positive perceptions? American Psychologist, 64, 231-240. http://dx.doi.org/10.1037/a0014718.

Dixon, J., Tredoux, C. Durrheim, K. Finchilescu, G., \& Clack, B. (2008). 'The inner citadels of the color line': Mapping the micro-ecology of racial segregation in everyday life spaces. Social and Personality Psychology Compass, 2, 1547-1569. https://doi.org/10.1111/j.1751-9004.2008.00123.x.

Dovidio, J. F., Eller, A., \& Hewstone, M. (2011). Improving intergroup relations through direct, extended and other forms of indirect contact. Group Processes and Intergroup Relations, 14, 147-160. https://doi.org/10.1177/1368430210390555.

Haddock, G., Zanna, M. P., \& Esses, V. M. (1993). Assessing the structure of prejudicial attitudes: The case of attitudes toward homosexuals. Journal of Personality and Social Psychology, 65, 1105-1118. http://dx.doi.org/10.1037/0022-3514.65.6.1105.

Harwood, J., Joyce, N., Chen, C. Y., Paolini, S., Xiang, J., \& Rubin, M. (2017). Effects of past and present intergroup communication on perceived fit of an outgroup member and desire for future intergroup contact. Communication Research, 44, 530-555. https://doi.org/10.1177/0093650214565926.

Hewstone, M., \& Brown, R. (1986). Contact is not enough: An intergroup perspective on the contact hypothesis. In M. Hewstone \& R. Brown (Eds.), Contact and conflict in intergroup encounters (pp. 1-44). Oxford, UK: Blackwell.

Hodson, G., Costello, K., \& MacInnis, C. C. (2013). Is intergroup contact beneficial among intolerant people? Exploring individual differences in the benefits of contact on attitudes. 
In G. Hodson, \& M. Hewstone (Eds.), Advances in Intergroup Contact (pp. 49-80). New York, NY: Psychology Press.

Houlette, M. A., Gaertner, S. L., Johnson, K. M., Banker, B. S., Riek, B. M., \& Dovidio, J. F. (2004). Developing a more inclusive social identity: An elementary school intervention. Journal of Social Issues, 60, 35-55. https://doi.org/10.1111/j.0022-4537.2004.00098.x. Joyce, N., \& Harwood, J. (2014). Improving intergroup attitudes through televised vicarious intergroup contact. Social cognitive processing of ingroup and outgroup information. Communication Research, 41, 627-643. https://doi.org/10.1177/0093650212447944.

Joyce, N., \& Harwood, J. (2018). Social identity motivations and intergroup media attractiveness. Group Processes \& Intergroup Relations. Advance online publication. https://doi.org/10.1177/1368430217751629.

Kaufman, G. F., \& Libby, L. K. (2012). Changing beliefs and behavior through experiencetaking. Journal of Personality and Social Psychology, 103, 1-19. http://dx.doi.org/10.1037/a0027525.

Liebkind, K., \& McAlister, A. L. (1999). Extended contact through peer modelling to promote tolerance in Finland. European Journal of Social Psychology, 29, 765-780. http://dx.doi.org/10.1002/(SICI)1099-0992(199908/09)29:5/6<765::AIDEJSP958>3.0.CO;2-J.

Liebkind, K., Mähönen, T. A., Solares, E., Solheim, E., \& Jasinskaja-Lahti, I. (2014). Prejudicereduction in culturally mixed classrooms: The development and assessment of a theorydriven intervention among majority and minority youth in Finland. Journal of Community \& Applied Social Psychology, 24, 325-339. https://doi.org/10.1002/casp.2168. 
Liebkind, K., Mäkinen, V., Jasinskaja-Lahti, I., Renvik, T. A., \& Solheim, E. F. (2019). Improving outgroup attitudes in schools: First steps toward a teacher-led vicarious contact intervention. Scandinavian Journal of Psychology, 60, 77-86. https://doi.org/10.1111/sjop.12505.

Long, A. C., Sanetti, L. M. H., Collier-Meek, M. A., Gallucci, J., Altschaefl, M., \& Kratochwill, T. R. (2016). An exploratory investigation of teachers' intervention planning and perceived implementation barriers. Journal of School Psychology, 55, 1-26. https://doi.org/10.1016/j.jsp.2015.12.002.

Mastro, D., \& Tukachinsky, R. (2011). The influence of exemplar versus prototype-based media primes on racial/ethnic evaluations. Journal of Communication, 61, 916-937. https://doi.org/10.1111/j.1460-2466.2011.01587.x.

Mazziotta, A., Mummendey, A., \& Wright, S. C. (2011). Vicarious intergroup contact effects: Applying social-cognitive theory to intergroup contact research. Group Processes and Intergroup Relations, 14, 255-274. https://doi.org/10.1177/1368430210390533.

McGuire, L., Rutland, A., \& Nesdale, D. (2015). Peer group norms and accountability moderate the effect of school norms on children's intergroup attitudes. Child Development, 86, 1290-1297. https://doi.org/10.1111/cdev.12388.

McIntyre, K., Paolini, S. \& Hewstone, M. (2016). Changing people's views of outgroups through individual-to-group generalisation: meta-analytic reviews and theoretical considerations. European Review of Social Psychology, 27, 63-115. https://doi.org/10.1080/10463283.2016.1201893

Olsson, M., Matera, C., Tip, L. K., \& Brown, R. (2017). The double-edged effect of intergroup similarity: Muslim and Christian immigrants' acculturation preferences on intergroup 
relations in Sweden. Group Processes \& Intergroup Relations. Advance online publication. https://doi.org/10.1177/1368430217740432

Özdemir, S. B., Sun, S., Korol, L., Özdemir, M., \& Stattin, H. (2018). Adolescents' engagement in ethnic harassment: Prejudiced beliefs in social networks and classroom ethnic diversity. Journal of Youth and Adolescence, 47, 1151-1163. https://doi.org/10.1007/s10964-017-0795-0

Paluck, E. L., \& Green, D. P. (2009). Prejudice reduction: What works? A review and assessment of research and practice. Annual Review of Psychology, 60, 339-367. https://doi.org/10.1146/annurev.psych.60.110707.163607.

Paluck, E. L., Green, S. A., \& Green, D. P. (2018). The contact hypothesis re-evaluated. Behavioural Public Policy. Advance online publication. https://doi.org/10.1017/bpp.2018.25

Pettigrew, T. F. (1998). Intergroup contact theory. Annual Review of Psychology, 49, 65-85. https://doi.org/10.1146/annurev.psych.49.1.65.

Pettigrew, T. F. (2018). The Emergence of Contextual Social Psychology. Social and Personality Psychology Bulletin, 44, 963-971. https://doi.org/10.1177/0146167218756033.

Schiappa, E., Gregg, P. B., \& Hewes, D. E. (2005). The parasocial contact hypothesis. Communication Monographs, 72, 92-115. https://doi.org/10.1080/0363775052000342544.

Solares, E., Huttunen, S., Mähönen, T. A., Hirvonen, M. \& Liebkind, K. (2012). Tarinoita kaveruudesta - hyviä kulttuurienvälisiä suhteita tukemassa. Opettajan opas (Stories about friendship - supporting good intercultural relations. Teacher's manual). Helsinki: Sosiaalipsykologian oppiaine ja Koulutus- ja kehittämiskeskus Palmenia, Helsingin 
yliopisto (Unit of Social Psychology and Palmenia Centre for Continuing Education, University of Helsinki).

Stathi, S., Cameron, L., Hartley, B., \& Bradford, S. (2014). Imagined contact as a prejudice-reduction intervention in schools: The underlying role of similarity and attitudes. Journal of Applied Social Psychology, 44, 536-546. https://doi.org/10.1111/jasp.12245.

Statistics Finland (2017). Population structure: Language according to age and sex by region in 1990 to 2016. Retrieved from http://pxnet2.stat.fi/PXWeb/pxweb/en/StatFin/StatFin__vrm_vaerak/statfin_vaerak_pxt _11rl.px/?rxid=3a735fba-4e6d-4d7e-a168-1986780df7b3

Thijs, J., \& Verkuyten, M. (2014). School ethnic diversity and students' interethnic relations. British Journal of Educational Psychology, 84, 1-21. https://doi.org/10.1111/bjep.12032.

Turner, R. N., \& Brown, R. (2008). Improving children's attitudes toward refugees: An evaluation of a school-based multicultural curriculum and an anti-racist intervention. Journal of Applied Social Psychology, 38, 1295-1328. https://doi.org/10.1111/j.15591816.2008.00349.x.

Turner, R. N., \& Cameron, L. (2016). Confidence in contact: A new perspective on promoting gross-group friendship among children and adolescents. Social Issues and Policy Review, 10, 212-246. https://doi.org/10.1111/sipr.12023.

Turner, T. N., Hewstone, M., \& Voci, A. (2007). Reducing explicit and implicit outgroup prejudice via direct and extended contact: The mediating role of self-disclosure and intergroup anxiety. Journal of Personality and Social Psychology, 93, 369-388. http://dx.doi.org/10.1037/0022-3514.93.3.369. 
Ülger, Z., Dette-Hagenmeyer, D. E., Reichle, B., Gaertner, S. L. (2018). Improving outgroup attitudes in schools: A meta-analytic review. Journal of School Psychology, 67, 88-103. https://doi.org/10.1016/j.jsp.2017.10.002.

Vedder, P., Horenczyk, G, Liebkind, K., \&. Nickmans, G. (2006). Ethno-culturally diverse education settings: problems, challenges and solutions. Educational Research Review, 1, 157-168. https://doi.org/10.1016/j.edurev.2006.08.007.

Verkuyten, M. \& Thijs, J. (2013) Multicultural education and inter-ethnic attitudes: An intergroup perspective. European Psychologist, 18, 179-190. https://doi.org/10.1027/1016-9040/a000152.

Vervoort, M. H. M., Ron H. J., Scholte, R. H. J., \& Scheepers, P. L. H. (2011). Ethnic composition of school classes, majority-minority friendships, and adolescents' intergroup attitudes in the Netherlands. Journal of Adolescence, 34, 257-267. https://doi.org/10.1016/j.adolescence.2010.05.005.

Vezzali, L., Hewstone, M., Capozza, D., Giovannini, D., \& Wölfer, R. (2014). Improving intergroup relations with extended and vicarious forms of indirect contact. European Review of Social Psychology, 25, 314-389. https://doi.org/10.1080/10463283.2014.982948.

Vezzali, L., Stathi, S., \& Giovannini, D. (2012). Indirect contact through book reading: Improving adolescents' attitudes and behavioral intentions toward immigrants. Psychology in the Schools, 49, 148-162. https://doi.org/10.1002/pits.20621.

Vezzali, L., Stathi, S., Giovannini, D., Capozza, D., \& Trifiletti, E. (2015a). The greatest magic of Harry Potter: Reducing prejudice. Journal of Applied Social Psychology, 45, 105-121. https://doi.org/10.1111/jasp.12279. 
Vezzali, L., Stathi, S., Giovannini, D., Capozza, D., \& Visintin, E. P. (2015b). “And the best essay is...": Extended contact and cross-group friendships at school. British Journal of Social Psychology, 54, 601-615. https://doi.org/10.1111/bjso.12110.

Visintin, E. P., Brylka, A., Green, E. G. T., Mähönen, T. A., \& Jasinskaja-Lahti, I. (2016). The dynamics of interminority extended contact: The role of affective and cognitive mediators. Cultural Diversity and Ethnic Minority Psychology, 22, 467-478. http://dx.doi.org/10.1037/cdp0000089.

Wright, S. C., Aron, A., McLaughlin-Volpe, T \& Ropp, S. A. (1997). The extended contact effect: Knowledge of cross-group friendship and prejudice. Journal of Personality and Social Psychology, 73, 73-90. http://dx.doi.org/10.1037/0022-3514.73.1.73. 


\section{VICARIOUS CONTACT INTERVENTION}

Table 1. Experimental design

$$
\text { Condition }
$$

\begin{tabular}{|c|c|c|}
\hline EXPERIMENTAL 1 & EXPERIMENTAL 2 & CONTROL \\
\hline $\begin{array}{c}\text { school A } \\
\text { (9 classes; } 100 \text { majority and } 26 \\
\text { minority students) }\end{array}$ & $\begin{array}{c}\text { school C } \\
\text { (7 classes; } 66 \text { majority and } 34 \\
\text { minority students) }\end{array}$ & $\begin{array}{c}\text { school } \mathbf{E} \\
\text { (11 classes; } 106 \text { majority and } \\
20 \text { minority students) }\end{array}$ \\
\hline $\begin{array}{c}\text { school B } \\
\text { (4 classes; } 45 \text { majority and } 15 \\
\text { minority students) }\end{array}$ & $\begin{array}{c}\text { school D } \\
\text { (3 classes; } 26 \text { majority and } 16 \\
\text { minority students) }\end{array}$ & $\begin{array}{c}\text { school } \mathbf{~} \\
\text { (9 classes; } 94 \text { majority and } 35 \\
\text { minority students) }\end{array}$ \\
\hline
\end{tabular}

\begin{tabular}{|c|c|c|c|}
\hline Week 1 & & T1 assessment & \\
\hline Week 2 & & Break & \\
\hline Week 3 & & Break & \\
\hline Week 4 & $\begin{array}{c}\text { SESSION 1: } \\
\text { majority storytellers } \\
\text { "Ville", boy, Finnish } \\
\text { "Sanna", girl, Finnish } \\
\text { "Aleksi", boy, Finnish } \\
\text { "Elina", girl, Finnish }\end{array}$ & $\begin{array}{c}\text { SESSION 1: } \\
\text { minority storytellers } \\
\text { “Andrei", boy, Russian } \\
\text { "Liis", girl, Estonian } \\
\text { "Faisal", boy, Iraqi } \\
\text { "Lien", girl, Vietnamese }\end{array}$ & No intervention \\
\hline Week 5 & $\begin{array}{l}\text { SESSION 2: } \\
\text { majority storytellers } \\
\text { "Karoliina", girl, Finnish } \\
\text { "Matias", boy, Finnish }\end{array}$ & $\begin{array}{c}\text { SESSION 2: } \\
\text { minority storytellers } \\
\text { “Aida”, girl, Turkish (Kurd) } \\
\text { “Abdi”, boy, Somalian }\end{array}$ & No intervention \\
\hline Week 6 & \multicolumn{3}{|c|}{ Break } \\
\hline Week 7 & \multicolumn{3}{|c|}{ T2 assessment } \\
\hline Week 8 & $\begin{array}{c}\text { SESSION 3: } \\
\text { minority storytellers } \\
\text { “Andrei", boy, Russian } \\
\text { "Liis", girl, Estonian } \\
\text { "Faisal", boy, Iraqi } \\
\text { "Lien", girl, Vietnamese }\end{array}$ & $\begin{array}{l}\text { SESSION 3: } \\
\text { majority storytellers } \\
\text { "Ville", boy, Finnish } \\
\text { "Sanna", girl, Finnish } \\
\text { "Aleksi", boy, Finnish } \\
\text { "Elina", girl, Finnish }\end{array}$ & No intervention \\
\hline Week 9 & $\begin{array}{c}\text { SESSION 4: } \\
\text { minority storytellers } \\
\text { “Aida”, girl, Turkish (Kurd) } \\
\text { "Abdi”, boy, Somalian }\end{array}$ & $\begin{array}{c}\text { SESSION 4: } \\
\text { majority storytellers } \\
\text { "Karoliina", girl, Finnish } \\
\text { "Matias", boy, Finnish }\end{array}$ & No intervention \\
\hline Week 10 & & Break & \\
\hline Week 11 & & T3 assessment & \\
\hline
\end{tabular}




\section{VICARIOUS CONTACT INTERVENTION}

Table 2. Mean perceived typicality of and perceived similarity with in- and outgroup storytellers in majority and minority samples

\begin{tabular}{|c|c|c|c|c|c|c|}
\hline \multirow[b]{2}{*}{ Measure } & \multicolumn{3}{|c|}{ Majority sample } & \multicolumn{3}{|c|}{ Minority sample } \\
\hline & $N$ & $M(S D)$ & $\begin{array}{c}\text { Difference between } \\
\text { storytellers }\end{array}$ & $N$ & $M(S D)$ & $\begin{array}{c}\text { Difference between } \\
\text { storytellers }\end{array}$ \\
\hline Perceived typicality (0-100) & 147 & & $t(146)=-.52, p=.605$ & 46 & & $t(45)=-.78, p=.441$ \\
\hline Ingroup storytellers & & $60.61(20.71)$ & & & $63.26(20.34)$ & \\
\hline Outgroup storytellers & & $61.56(21.16)$ & & & $60.43(17.51)$ & \\
\hline Perceived similarity (0-100) & 149 & & $t(148)=1.96, p=.052$ & 45 & & $t(44)=-.18, p=.861$ \\
\hline Ingroup storytellers & & $36.98(25.86)$ & & & 40.67 (31.07) & \\
\hline Outgroup storytellers & & $32.62(22.70)$ & & & $39.78(28.72)$ & \\
\hline
\end{tabular}




\section{VICARIOUS CONTACT INTERVENTION}

Table 3. Means, standard deviations and intra-class correlations (ICC) of dependent measures at $\mathrm{T} 1$ for majority and minority samples

\begin{tabular}{|c|c|c|c|c|c|c|c|c|}
\hline \multirow[b]{2}{*}{ Measure } & \multicolumn{4}{|c|}{ Majority sample } & \multicolumn{4}{|c|}{ Minority sample } \\
\hline & $N$ & $M(S D)$ & ICC class & ICC school & $N$ & $M(S D)$ & ICC class & ICC school \\
\hline Outgroup attitudes $(0-100)$ & & & .026 & .041 & & & $<.001$ & $<.001$ \\
\hline experimental & 237 & $67.47(23.21)$ & & & 90 & $75.22(21.74)$ & & \\
\hline control & 198 & $60.51(24.34)$ & & & 53 & $73.58(23.13)$ & & \\
\hline Ingroup norms (1-5) & & & .023 & .003 & & & $<.001$ & .021 \\
\hline experimental & 233 & $3.16(.73)$ & & & 87 & $3.75(.79)$ & & \\
\hline control & 196 & $3.03(.74)$ & & & 52 & $3.61(.67)$ & & \\
\hline Outgroup norms (1-5) & & & $<.001$ & $<.001$ & & & $<.001$ & .022 \\
\hline experimental & 237 & $3.39(.74)$ & & & 88 & $3.32(.85)$ & & \\
\hline control & 197 & $3.37(.63)$ & & & 52 & $3.56(.74)$ & & \\
\hline
\end{tabular}

Note. Higher values denote more positive attitudes and perceived in- and outgroup norms. 


\section{VICARIOUS CONTACT INTERVENTION}

Table 4. The result of 2 (Time) x 2 (Experimental sub-group) mixed design ANOVAs for majority and minority samples.

\begin{tabular}{|c|c|c|c|c|c|c|c|c|c|c|c|c|}
\hline \multirow[b]{3}{*}{$\begin{array}{l}\text { Dependent measures } \\
\text { per experimental sub- } \\
\text { group }\end{array}$} & \multicolumn{6}{|c|}{ Majority sample } & \multicolumn{6}{|c|}{ Minority sample } \\
\hline & & $\begin{array}{l}\mathrm{T} 1 \\
\text { Pre- } \\
\text { intervention }\end{array}$ & $\begin{array}{l}\text { T2 } \\
\text { Mid- } \\
\text { intervention }\end{array}$ & $\begin{array}{l}\text { Main } \\
\text { effect } \\
\text { for } \\
\text { time }\end{array}$ & $\begin{array}{l}\text { Time x. } \\
\text { Sub- } \\
\text { group }\end{array}$ & ES & & $\begin{array}{l}\text { T1 } \\
\text { Pre- } \\
\text { intervention }\end{array}$ & $\begin{array}{l}\text { T2 } \\
\text { Mid- } \\
\text { intervention }\end{array}$ & $\begin{array}{c}\text { Main } \\
\text { effect } \\
\text { for } \\
\text { time }\end{array}$ & $\begin{array}{l}\text { Time } x \\
\text { Sub- } \\
\text { group }\end{array}$ & $\mathrm{ES}$ \\
\hline & $\mathrm{N}$ & $M(S D)$ & $M(S D)$ & $F$ & $F$ & $\begin{array}{c}\text { Partial } \\
\eta^{2}\end{array}$ & $\mathrm{~N}$ & $M(S D)$ & $M(S D)$ & $F$ & $F$ & $\begin{array}{c}\text { Partial } \\
\eta^{2}\end{array}$ \\
\hline $\begin{array}{l}\text { Outgroup attitudes } \\
(0-100)\end{array}$ & & & & .04 & .03 & .000 & & & & 1.09 & .33 & .004 \\
\hline majority storytellers & $\begin{array}{c}14 \\
4\end{array}$ & $\begin{array}{c}67.01 \\
(23.98)\end{array}$ & $\begin{array}{c}67.71 \\
(23.94)\end{array}$ & & & & 41 & $\begin{array}{c}78.78 \\
(18.87)\end{array}$ & $\begin{array}{c}80.98 \\
(17.86)\end{array}$ & & & \\
\hline minority storytellers & 91 & $\begin{array}{c}67.69 \\
(22.01)\end{array}$ & $\begin{array}{c}68.57 \\
(21.48)\end{array}$ & & & & 47 & $\begin{array}{c}73.83 \\
(22.61)\end{array}$ & $\begin{array}{c}75.11 \\
(22.54)\end{array}$ & & & \\
\hline Ingroup norms (1-5) & & & & 3.45 & .72 & .003 & & & & .18 & 2.13 & .027 \\
\hline majority storytellers & $\begin{array}{c}14 \\
0\end{array}$ & $3.15(.73)$ & $3.18(.73)$ & & & & 40 & $3.98(.79)$ & $3.98(.70)$ & & & \\
\hline minority storyteller & 90 & $3.15(.74)$ & $3.28(.71)$ & & & & 44 & $3.55(.77)$ & $3.45(.75)$ & & & \\
\hline Outgroup norms (1-5) & & & & .79 & .12 & .001 & & & & .24 & 1.57 & .019 \\
\hline majority storytellers & $\begin{array}{c}14 \\
2\end{array}$ & $3.39(.72)$ & $3.44(.74)$ & & & & 40 & $3.52(.86)$ & $3.46(.86)$ & & & \\
\hline minority storytellers & 91 & $3.39(.77)$ & $3.43(.73)$ & & & & 47 & $3.13(.81)$ & $3.31(.70)$ & & & \\
\hline
\end{tabular}

Note. Higher values denote more positive attitudes and perceived in- and outgroup norms. 


\section{VICARIOUS CONTACT INTERVENTION}

Table 5. The result of 2 (Time) x 2 (Condition) mixed design ANOVAs for majority and minority samples.

\begin{tabular}{|c|c|c|c|c|c|c|c|c|c|c|c|c|}
\hline \multirow[b]{3}{*}{$\begin{array}{l}\text { Dependent } \\
\text { measures per } \\
\text { condition }\end{array}$} & \multicolumn{6}{|c|}{ Majority sample } & \multicolumn{6}{|c|}{ Minority sample } \\
\hline & & $\begin{array}{l}\mathrm{T} 1 \\
\text { Pre- } \\
\text { intervention }\end{array}$ & $\begin{array}{l}\mathrm{T} 3 \\
\text { Post- } \\
\text { intervention }\end{array}$ & $\begin{array}{l}\text { Main } \\
\text { effect } \\
\text { for } \\
\text { time }\end{array}$ & $\begin{array}{l}\text { Time } \mathrm{x} \\
\text { Condi- } \\
\text { tion }\end{array}$ & ES & & $\begin{array}{l}\mathrm{T} 1 \\
\text { Pre- } \\
\text { intervention }\end{array}$ & $\begin{array}{l}\mathrm{T} 3 \\
\text { Post- } \\
\text { intervention }\end{array}$ & $\begin{array}{c}\text { Main } \\
\text { effect } \\
\text { for } \\
\text { time }\end{array}$ & $\begin{array}{l}\text { Time } x \\
\text { Condi- } \\
\text { tion }\end{array}$ & ES \\
\hline & $\mathrm{N}$ & $M(S D)$ & $M(S D)$ & $F$ & $F$ & $\begin{array}{c}\text { Partial } \\
\eta^{2}\end{array}$ & $\mathrm{~N}$ & $M(S D)$ & $M(S D)$ & $F$ & $F$ & $\begin{array}{c}\text { Partia } \\
\eta^{2}\end{array}$ \\
\hline $\begin{array}{l}\text { Outgroup } \\
\text { attitudes }(0-100)\end{array}$ & & & & $5.85 *$ & $5.99 *$ & .014 & & & & .60 & .16 & .001 \\
\hline Experimental & 235 & $\begin{array}{c}67,45 \\
(23,23)\end{array}$ & $\begin{array}{c}67,96 \\
(22,87)\end{array}$ & & & & 86 & $\begin{array}{c}76,05 \\
(20,99)\end{array}$ & $\begin{array}{c}76,28 \\
(24,26)\end{array}$ & & & \\
\hline Control & 188 & $\begin{array}{c}61,70 \\
(23,70)\end{array}$ & $\begin{array}{c}66,81 \\
(24,35)\end{array}$ & & & & 52 & $\begin{array}{c}74,42 \\
(22,53)\end{array}$ & $\begin{array}{c}77,12 \\
(19,94)\end{array}$ & & & \\
\hline $\begin{array}{l}\text { Ingroup norms } \\
(1-5)\end{array}$ & & & & $9.60 * *$ & .15 & .000 & & & & .11 & .08 & .001 \\
\hline Experimental & 231 & $3,17(, 73)$ & $3,29(, 75)$ & & & & 82 & $3,76(, 81)$ & $3,78(, 75)$ & & & \\
\hline Control & 185 & $3,05(, 73)$ & $3,15(, 74)$ & & & & 50 & $3,63(, 67)$ & $3,59(, 80)$ & & & \\
\hline $\begin{array}{l}\text { Outgroup } \\
\text { norms (1-5) }\end{array}$ & & & & .02 & .13 & .000 & & & & 1.64 & $5.78 *$ & .045 \\
\hline Experimental & 232 & $3,40(, 73)$ & $3,41(, 76)$ & & & & 82 & $3,30(, 86)$ & $3,55(, 78)$ & & & \\
\hline Control & 186 & $3,41(, 61)$ & $3,41(, 71)$ & & & & 50 & $3,58(, 75)$ & $3,52(, 72)$ & & & \\
\hline
\end{tabular}

Note. Higher values denote more positive attitudes and perceived in- and outgroup norms.

$* p<.05, * * p<.01$ 
APPENDIX: Two examples of the friendship stories read in the intervention

\section{ANDREI}

Andrei comes from Russia. He is in eighth grade and plays basketball in his free time.

"Even though I kept meeting Finnish people all the time at school, for example, I didn't have close Finnish friends in quite a long time. At first that was obviously because I didn't know much Finnish, so it was easier to be only with Russians. But it was also like I was nervous when I was around Finns as I thought that Finns don't want to be with Russian anyway. That changed when I started playing basketball in a team. Most guys in my team are Finnish, and they were the first Finns I got to know better. I didn't believe that they would accept me into that team. I had to admit that I had been wrong.

I have a couple of good friends in the basketball team now, Niko and Jesse and we meet up at practice, of course, but at other times too. These guys are really cool! In summer when we have more free time we like to sit somewhere outside and in winter we play PlayStation together. And sometimes we hang out also with my Russian friends. It is important that everyone get along as we're all living in the same country."

\section{ELINA}

Eight-grader Elina plays volleyball. She goes to practice three times a week.

"At my school, the teachers have always been really strict on nobody getting bullied or discriminated, although some people still bullied foreigners at school. I didn't bully anyone, but I felt much easier to be just with Finns. Then we once had a discussion at school where we talked 
about how it would feel like if you moved somewhere else and didn't have your friends there to help you.

At the time I was doing practical professional orientation in a shop and there was also a girl from Vietnam called Lien. She told me that she had been bullied in school because she's Vietnamese. Then I remembered the discussion at school. I started thinking about how I would feel if I was not respected only because I happened to come from a different place. Now we're already good friends with Lien. I've noticed that it's just as easy to be with her as with Finns. I think that the bullies behave like they do because they don't even really know anyone who comes from another country. I'd like them to get to know someone as smart as Lien. Lien has travelled much more than me and I think it's really fun to hear about her travels." 